International Journal of Arts and Humanities Studies (IJAHS)

ISSN: $2754-4311$

DOI: 10.32996/ijahs

Journal Homepage: www.al-kindipublisher.com/index.php/ijahs

\title{
School On Wheels and Multimedia-Aided Instructions as Mediators of Students' Local Cultural Heritage Awareness
}

\author{
Dr. John Erwin Prado Pedroso \\ Faculty, College of Education, Professional Education Department, Adviser, Education Student Council \& 35 Society (Social \\ Science Students' Society) (UNESCO Accredited Organizations in the Philippines), West Visayas State University La Paz, Iloilo \\ City, Philippines
}

$\square$ Corresponding Author: Dr. John Erwin Prado Pedroso, E-mail: johnerwin.pedroso@wvsu.edu.ph

ARTICLE INFO

Received: 12 October 2021

Accepted: 10 November 2021

Published: 23 November 2021

DOI: 10.32996/ijahs.2021.1.1.10

\section{KEYWORDS}

School On Wheels, Multimedia-

Aided Instructions, Local Cultural

Heritage Awareness

\section{ABSTRACT}

Countless stories are told about local heritage sites. Because these stories are one-ofa-kind, they present a significant challenge to students' knowledge and awareness of their cultural background. Furthermore, literature is scarce on students' historical and architectural knowledge of local cultural heritage places. This study determined the level of local cultural heritage sites knowledge of sixty (60) students through school on wheels and multimedia-aided instructions. The study made use of a duly-validated researcher-made Local Cultural Heritage Sites Questionnaire. Frequency count, mean, and standard deviation were the descriptive statistics used while t-test was used for inferential statistics set at 0.05 level of significance using the Statistical Packages for Social Sciences (SPSS) software. The results revealed that the level of students' historical and architectural knowledge of local cultural heritage sites was "moderate" and shifted to "high" when school on wheels and multimedia-aided instructions were introduced. There were significant differences in the historical and architectural knowledge of the students on local cultural heritage sites. Students' knowledge is improved via teaching and learning activities that give experiential and meaningful learning. Increased local cultural heritage knowledge of students is a step forward in promoting cultural heritage conservation and preservation.

\section{Introduction}

Cultural heritage has been researched extensively as a reflection of past and present knowledge, works, values, beliefs, structures, and practices that give identity to the society to which it belongs (Karadeniz, 2020). As historians and educators employ the study of local cultural heritage to reach the minds of today's students, interest in local cultural heritage is expanding (Santos, 2021). Recent research has focused on the historical, cultural, and economic importance of heritage on tourism (Göebakan, 2016); the aesthetic and scientific significance of heritage on cultural identity (Vecco, 2010; Tören, Kozak \& Demiral, 2012; Hazler, 2012; Karadeniz, 2020); and new learning opportunities (Oğuz, 2013) in education, because it incorporates not only knowledge but also skills and civic values, students' awareness of local cultural heritage has become a crucial concern (Felices-Dela Fuente, ChaparroSainz, and Rodriguez-Perez, 2020). Field trips, as Külcü (2015) emphasizes the role of technology in teaching about local cultural heritage (Ocal, 2016), are an excellent way to employ experiential learning in teacher education (Djonko-Moore \& Joseph, 2016).

Previous research on local cultural heritage hasn't looked into the benefits of combining multimedia-aided instruction with a field trip on students' awareness. Despite being based in a school setting, studies such as those on cultural heritage protection (Karadeniz, 2020) and the development of social and civic skills (Felices-Dela Fuente, Chaparro-Sainz, and Rodriguez-Perez, 2020) are unsatisfactory. To increase cultural heritage awareness (Kardeniz, 2020), history learning (Margo, de Carvalho, \& Marcelino, 2014), personal interest (Ahmed, 2017), and perceptions of universal cultural heritage values and assets (Karedeniz, 2020) should not only be the focus of local cultural heritage researches. As a result, a focus is placed on developing students' understanding of

Copyright: (c) 2021 the Author(s). This article is an open access article distributed under the terms and conditions of the Creative Commons Attribution (CC-BY) 4.0 license (https://creativecommons.org/licenses/by/4.0/). Published by Al-Kindi Centre for Research and Development, London, United Kingdom. 
local cultural heritage through multimedia (Ilhan \& Oruç, 2016) and field trips as a kind of students' experiential learning (DjonkoMoore \& Joseph, 2016).

The goal of this action research is to determine the level of students' local cultural heritage awareness as mediated multimediaaided instruction and school-on-wheels. It was expected that after the interventions, students' local cultural heritage awareness will be significantly different. Furthermore, the findings of this research will shed light on how the combination of technology and an immersive approach to teaching and learning about local cultural heritage might benefit students. Similarly, this could open up research prospects for improving the local tourism economy, promoting cultural assets, and influencing legislation.

\section{Literature Review}

Most history teachers and educators are concerned about how to teach history effectively. This is because most history teachers do not use effective teaching approaches when teaching the topic. As a result, the majority of students regard History as a tedious and boring subject (Boadu, 2015). According to Fogo (2014), effective history education is less likely in a traditional History classroom setting "where curriculum spans long periods, teachers deliver content-heavy lectures, and students take notes and scour texts to memorize data" (p. 153). It requires History teachers to be proactive and goal-oriented in the discipline, rather than simply knowing how to teach "anything." Therefore, experiential learning and learning aided with technology is inevitable among the younger generation to study history, especially lessons on local cultural heritage.

According to a study conducted in Turkey, multimedia techniques improved students' academic progress in social studies lessons when compared to traditional classrooms (Ilhan \& Oruç, 2016). Multimedia-Aided Teaching is also more effective than traditional teaching, according to a study conducted in Pakistan (Shah \& Khan, 2015). According to a study conducted by Narzoles in Bahrain (2013), students who received multi-media instruction performed better than students who received traditional instruction. As Gilakjani (2012) presented three justifications and arguments for employing multimedia in the classroom, its use, he argues, increases students' involvement, comprehension, and memory capacity.

Furthermore, Moore and Jospeh (2016) discovered that students enjoyed the field trips but were concerned about the time and distance. They were able to make critical connections to course content, but they objected to the field trips' embrace of diversity. Yeşilbursa and Barton (2011) discovered that all of the registered pre-service teachers enjoyed the trip and were able to make links to heritage education in a social studies course. They also established linkages to their future teaching practices by expressing a desire to employ historical sites as teaching resources. Historic sites are particularly valuable in teaching since they are concrete and make history engaging, according to the teacher candidates. Students will learn about lessons in architecture as they learn about history through cultural heritage sites, according to Atalan (2018), who discussed the importance of cultural heritage and conservation concepts in architecture education, as well as the adequacy of conservation and cultural heritage courses in the curriculum.

\section{Methodology}

\subsection{Intervention}

The researcher used School on Wheels and multimedia-aided instruction for class discussion as interventions to the existing problem in an action research project to see if they help students learn more about local Cultural Heritage.

Text, color, graphical graphics, animation, audio-sound, and full-motion video concerning the lloilo Cultural Heritage Sites were included in the multimedia-assisted training. Five multimedia-aided presentations focusing on the architectural and historical context of the several Iloilo Cultural Heritage Sites were developed. These five presentations were validated by a five-person jury consisting of a computer programmer and tourism educators. Suggestions for modifications and improvements were taken into account and incorporated into the final presentations. On the other hand, School On Wheels was designed for students to visit various local Cultural Heritage Sites around the city's seven (7) districts. School on Wheels activity, short lectures on the cultural heritage site's historical and architectural context were given.

\subsection{Participants}

There sixty (60) randomly chosen participants determined through the use the Slovin's formula. The fishbowl technique was used in choosing the participants which consisted of thirty (30) male and thirty (30) female participants. These students were students of a local institution.

\subsection{Data Gathering Instrument}

The researcher-made Local Cultural Heritage Questionnaire was employed in this study. It included a 40-item multiple-choice test on historical and architectural-related items. The questionnaire was presented to a panel of five experts in the fields of curriculum 
and instruction, as well as tests and measurement. The comments and recommendations of the jurors were incorporated into the final form of the Questionnaire on Local Cultural Heritage Sites. Every correct answer received one point.

\subsection{Procedures}

The students were given the Local Cultural Heritage Questionnaire by the researcher. The intervention was given to the participants for six (6) weeks which started with a pre-test. The treatment which included multimedia-aided instruction and School On Wheels began in the second week of January and lasted until the third week of February. After six (6) weeks of intervention, the participants were given the posttest to determine if there is an improvement in their local cultural heritage awareness.

\subsection{Steps in the Collection of Data}

The Dean was asked for permission to conduct action research. The researcher personally distributed and delivered the test questionnaires to the study participants as soon as authorization was obtained. The individuals were given a pretest and a posttest after six (6) weeks by the researcher. The answers of the students were double-checked, and the results were collated, computed, and recorded. The pretest and posttest mean values were compared. The following scale is used to determine the level of historical and architectural knowledge of students.

\begin{tabular}{|l|l|}
\hline \multicolumn{1}{|c|}{ Scale } & Description \\
\hline $16.01-20.00$ & Very High \\
\hline $12.01-16.00$ & High \\
\hline $8.01-12.00$ & Moderate \\
\hline $4.01-8.00$ & Low \\
\hline $1.00-4.00$ & Very Low \\
\hline
\end{tabular}

\subsection{Data Analysis Procedure}

The computer software utilized for data analysis was the Statistical Packages for Social Sciences (SPSS) software. Continuous data was given in means and standard deviations, whereas categorical data was provided in frequency counts. A t-Test for related samples was used to examine the significance of the variations in the students' historical and architectural knowledge acquired from the pre-test and post-test mean scores. If the p-value was smaller than . 05 , the outcome was significant in this study.

\section{Results}

Table 1. Students' Historical Knowledge

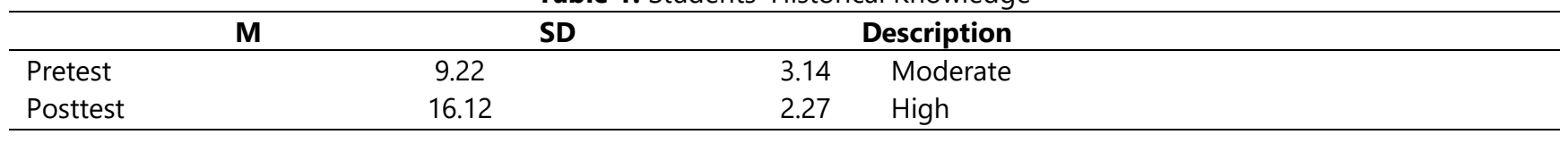

Table 1 shows the level of students' historical knowledge before and after the School On Wheels and multimedia-aided instructions were introduced. In the pre-test, the level of students' historical knowledge was moderate $(M=9.22, S D=3.14)$. It shifted to high $(M=16.12, S D=2.27)$ in the posttest.

In the pre-test, students have prior knowledge about the historical significance of the different cultural heritage sites through the books that they read and stories shared with them by people which guaranteed a moderate historical knowledge. However, students' visits to the heritage sites perhaps influenced students' high historical knowledge in the post-test. Through the School on Wheels to museums, ancestral houses, and churches helped students relate their prior knowledge of historical events by seeing the clothing of different eras, touching the transportation used, and reading about the era in the context of who the people of that era were related to the heritage sites.

On the other hand, students' historical knowledge improved as they became interested and entertained by the multimedia-aided presentations which included videos, pictures, and animated texts which paved the way for a lively class interaction in learning historical events.

Table 2. Students' Architectural Knowledge

\begin{tabular}{|c|c|c|c|}
\hline & $\mathbf{M}$ & SD & Description \\
\hline Pretest & 11.28 & 3.17 & Moderate \\
\hline Posttest & 15.73 & 2.81 & High \\
\hline
\end{tabular}


Table 2 shows the level of students' architectural knowledge before and after the School On Wheels and multimedia-aided instructions were introduced. In the pre-test, the level of students' historical knowledge was moderate $(M=11.28, S D=3.14)$. It shifted to high $(M=15.73, S D=2.18)$ in the posttest.

In the pre-test, students might find it difficult to understand the architectural designs of the different cultural heritage sites as they only read those from the book. Their way of learning was perhaps to memorize the verbatim definition of technical terms which they might have forgotten during their exams. It became high in the posttest by having actual observation of the building designs through School On Wheels and which might be strengthened the teachers' additional information.

It is possible that students' architectural knowledge increased through the use of multimedia-aided instruction because video clips, pictures, and animated texts were included in the multimedia-aided presentation that provided students with computer-generated three-dimensional (3D) images. The inclusion of promotional videos of the cultural heritage sites allowed students to closely appreciate the architectural designs of cultural heritage sites in the course of class discussion.

Table 3. Difference in Students' Historical Knowledge

\begin{tabular}{llcc}
\hline & Df & t-value & Sig. \\
\hline $\begin{array}{l}\text { Pretest } \\
\text { Posttest }\end{array}$ & 59 & 22.60 & \multirow{2}{*}{0.00} \\
\hline & & ${ }^{*} p<0.05$, significant &
\end{tabular}

Table 4 shows a significant difference in students' historical knowledge after the School On Wheels and multimedia-aided instruction were introduced, $t(59)=22.60, p<.0 .05$.

The result was perhaps influenced by how School on Wheels made students learn history beyond the four walls of the classroom. Furthermore, students might be very appreciative of learning historical events through School on Wheels that made history tangible rather than abstract as they became interactive with museum exhibits. On the other hand, the use of multimedia-aided instruction in the teaching of heritage sites was likely the most appreciated teaching strategy aside from the traditional lecture method. The combination of animated text, pictures, and video clips might be the language of students to be more motivated in learning historical information as students today are technological savvy.

Moreover, students' historical knowledge could be brought by a very stimulating discussion through the multimedia-aided presentation while seeing photos of prominent people, places, clothing, transportation, and video that retell historical events.

Table 4. Difference in Students' Architectural Knowledge

\begin{tabular}{rccc}
\hline & Df & t-value & Sig. \\
\hline $\begin{array}{c}\text { Pretest } \\
\text { Posttest }\end{array}$ & 59 & 22.60 & \multirow{2}{*}{0.00} \\
\hline & & ${ }^{*} p<0.05$, significant
\end{tabular}

Table 4 shows a significant difference in students' architectural knowledge after the School On Wheels and multimedia-aided instruction were introduced, $t(59)=27.42, p<.0 .05)$.

The School on Wheels might give students opportunities to closely observe and appreciate heritage buildings, old houses, churches, and museums. Thus, students learned architectural designs unique to the heritage site and broadened their architectural knowledge through seeing simple to intricate wall carvings, roof designs, and decorative pillars that would pose a distinct architectural character to a particular heritage site. Through this, students remembered the details efficiently thus, a significant difference in students' architectural knowledge was exposed.

Likewise, multimedia-aided instructions provided students with videos and pictures to further appreciate the architectural designs of churches, museums, buildings, and old mansions. Moreover, architectural designs perhaps came very handily to the students as they were closely shown during the multimedia-aided class discussions. Photos of different churches that show different architectural designs presented in the multimedia-aided presentation allowed students to differentiate one design from the other. It could also be possible that students were highly entertained by the multimedia-aided presentation that showed the unique architectural designs of different heritage sites. 


\section{Discussion}

Because cultural heritage awareness is such an important part of heritage preservation and management (Srivastava, 2015), developing cultural awareness takes time and requires the commitment and assistance of the local community (Boyle-Baise, 2000; Boyle-Baise \& Sleeter, 2000; Hovater, 2007; Srivastava, 2015; Stachowski \& Visconti, 1997). The United Nations General Assembly designated the Decade of Education for Sustainable Development in December 2002 to raise awareness of local cultural heritage preservation (Carbone et al., 2012). As a result, this action research looked into students' awareness of local cultural heritage as mediated by the School On Wheels and multimedia-aided instruction.

After School On Wheels and multimedia-aided instruction were introduced, the level of students' local cultural heritage awareness shifted from moderate to high, with a significant difference. The findings of this study implied that to raise students' local cultural heritage awareness of students, teachers should use a variety of tools to teach cultural heritage (Boxtel et al., 2011). Onsite visits to heritage sites are an effective link for students (Smith, 2003) and the use of technology has a significant impact on learning about local cultural heritage (Ott \& Pozzi, 2011). Some researchers showed how onsite visits and technology work together to facilitate efficient learning of local cultural heritage. Culture and cultural heritage issues are important in non-traditional education systems since they stimulate teamwork, leadership, research, and presentation (Alkateb, 2013). According to Apostolopoulou et al. (2014), active engagement in real-life learning activities result in gaining new skills and information while rediscovering the local environment. With technology, classroom discussion can now include virtual field trips unlike what the study of Antonaci, et al. (n.d.) highlighted, that the use of virtual museums in schools is still infrequent and not fully introduced in the standard educational practice. As teachers' digital competence in the use and knowledge of specific technical resources for cultural heritage education (Ibáez-Etxeberria et al., 2019) is crucial, for effectively using multimedia-aided presentations becomes the source of a real methodological change in the classroom (Marquès, 2013). Furthermore, field trips create tangible links between field experiences (Sevier, 2005) and teaching culture and history, strengthening students' identities through the use of technology toward academic, social, and political empowerment (Wu, 2011). Students' local cultural heritage awareness will not only increase through School On Wheels and multimedia-assisted instruction, but they will also gain skills, learn to examine the history and be prepared as citizens who embrace democratic ideals (Lobovikov-Katz, 2019). Furthermore, future generations will be better able to comprehend the facts of the situation (Pedroso, 2021), allowing them to cherish, care for, and protect the culture (Pedroso, 2020)

\section{Conclusion}

Local cultural heritage sites are efficient teaching and learning resources. When multimedia-aided instruction and the School on Wheels are effectively utilized, students learn more about their local cultural heritage sites. As School on Wheels gives a unique chance to learn about local cultural heritage sites, both students and teachers look forward to something to look forward to as a change from the typical classroom-based teaching and learning approaches. Multimedia-assisted instruction, on the other hand, is significant assistance in improving students' higher learning with the aid of technology. Once teachers successfully integrated multimedia-aided presentations in class discussions, students became more interested in learning about their local cultural heritage sites. The more we become knowledgeable of our local culture, the more we are connected as a people. As we take conscious efforts of protecting our local cultural heritage, the more that our future generations will benefit as a nation.

Acknowledgments: The researcher wishes to express his heartfelt gratitude to everyone who helped and made this study work feasible in some way. Sano and Aida, his parents. Pope, his brother, are in the same boat. To God be the glory!

Funding: This research received no external funding.

Conflicts of Interest: The authors declare no conflict of interest.

\section{References}

[1] Atalan, Ö. (2018). Importance of cultural heritage and conservation concept in the "architectural education". International Journal of Human Sciences, 15 (3), 1700-1710.

[2] Abdelazim-Ahmed, T.S. (2017). Assessment of students' awareness of the national heritage (Case study: The preparatory year students at the University of Hail, Saudi Arabia). Cogent Social Sciences, 3: 1306202 http://dx.doi.org/10.1080/23311886.2017.1306202

[3] Akkuş, G., Karaca, Ş. Polat, G. (2015). Heritage awareness and experience: an exploratory study on university students. Akademik Bakış Dergisi, 50,71-81.

[4] Alkateb, M. (2013). Non-traditional education using cultural heritage: A case study from Syria. International Journal of Education Through Art. 9. 189-204. 10.1386/eta.9.2.189_1.

[5] Antonaci, A., Ott, M., \& Pozzi, F. (n.d.). Virtual museums, cultural heritage education, and 21st-century skills. International Journal of Applied Engineering Research.

[6] Apostolopoulou, A. P., Carvoeiras, L. M., \& Klonari, A. (2014, November). Cultural Heritage and education: Integrating tour maps in a Bilateral Project. European Journal of Geography, 5, 67-77 
[7] Arıkan, İ.; Doğan, Y. (2013). Analyzing the success levels and attitudes of elementary education 7th grade students related to cultural heritage (Adıyaman province case). Adıyaman Üniversitesi Sosyal Bilimler Enstitüsü Dergisi, 6 (15), 29-68.

[8] Boadu, G., (2015). Effective Teaching in History: The Perspectives of History Student-Teachers, International Journal of Humanities and Social Sciences. 3 (1), 38-51. p-ISSN: 1694-2620 e- ISSN: 1694-2639

[9] Boxtel, C. V., Klein, S., Snoep, E. (2011, September). Heritage education Challenges in dealing with the past. ISBN 978-90-78956-19-8.

[10] Boyle-Baise, M. (2000). Multicultural service-learning: Educating teachers in diverse communities. New York, NY: Teachers College Press.

[11] Boyle-Baise, M., \& Sleeter, C. E. (2000). Community-based service learning for multicultural teacher education. Educational Foundations, 14, 33-50.

[12] Buluk, B. (2017). Cultural heritage awareness of tourism undergraduate students: the case of Çanakkale Onsekiz Mart University. International Congress of Tourism and Cultural Heritage, Muğla.

[13] Carbone, F., Oosterbeek, L., \& Costa, C. (2012). The educational and awareness purposes of the Paideia approach for heritage management. Natural Hazards and Earth System Science, 12, 1983-1986. http://dx.doi.org/10.5194/nhess-12-1983-2012

[14] Djonko-Moore, C. M., \& Joseph, N. M. (2016). Out of the Classroom and into the City: The Use of Field Trips as an Experiential Learning Tool in Teacher Education. SAGE Open. https://doi.org/10.1177/2158244016649648

[15] Donmez, C., \& Yesilbursa, C. C. (2014). The Effect of Cultural Heritage Education on Students' Attitudes Toward Tangible Heritage. Elementary Education Online, 13, 425-442. http://ilkogretim-online.org.tr

[16] Felices-De la Fuente, M.d.M., Chaparro-Sainz, Á. \& Rodríguez-Pérez, R.A. Perceptions on the use of heritage to teach history in Secondary Education teachers in training. Humanit Soc Sci Commun 7, 123(2020).https://doi.org/10.1057/s41599-020-00619-3

[17] Fogo, B. (2014). Core practices for teaching history: The results of a Delphi panel survey. Theory \& Research in Social Education, 42(2), 151196, DOI: 10.1080/00933104.2014.902781.

[18] Gilakjani, A. P. (2012). The significant role of multimedia in motivating EFL learners' interest in English language learning. I.J.Modern Education and Computer Science, 4, 57-66. http://www.mecs-press.org/ijmecs/ijmecs-v4-n4 /JMECS-V4-N4-8.pdf

[19] Göğebakan, Y. (2016). The contribution of word's cultural entities to tourism and economy. Anadolu Üniversitesi Güzel Sanatlar Enstitüsü Sanat ve Tasarım Dergisi, 1 (5), 48-77.

[20] Hazler, V. (2012). Perception of cultural heritage and monument protection. Traditions, 41 (2), 123-

134.

[21] Hovater, S. E. (2007). Developing cultural awareness: A grounded theory study of pre-service teachers' field experiences in Taiwan. Lincoln, NE: University of Nebraska. Retrieved from http://digitalcommons.unl.edu/cgi/ view content.cgi?article=1013\&context $=$ cehsdiss

[22] Ibáñez-Etxeberria A, Kortabitarte A, De Castro P, Gillate I (2019) Competencia digital mediante apps de temática patrimonial en el marco DigComp. Rev Electrón Interuniv Form Profr 22(1):13-27

[23] Karadeniz B, C. (2020). Assessment for Awareness and Perception of the Cultural Heritage of Geography Students. Review of International Geographical Education Online, Special Issue, 40-64. DOI: 10.33403/rigeo.640722

[24] Kruchten, P., Lago, P., van Vliet, H.: Building up and Reasoning about Architectural Knowledge. In: Hofmeister, C., Crnkovic, I., Reussner, R. (eds.) QoSA 2006. LNCS, vol. 4214, pp. 39-47. Springer, Heidelberg (2006) https://doi.org/10.1007/11921998_8

[25] Külcü, Ö. T. (2015). The importance of the concept of cultural heritage in education. Akademia Disiplinlerarası Bilimsel Araştırmalar Dergisi, 1 (1), 27-32.

[26] Lobovikov-Katz, A. (2019). Methodology for Spatial---Visual Literacy (MSVL) in Heritage Education: Application to Teacher Training and Interdisciplinary Perspectives. 10.6018/reifop.22.1.358671.

[27] Magro, G., de Carvalho, J.R., and Marcelino,M.J. ( 2014). Improving history learning through cultural heritage, local history, and technology. ISBN: 978-989-8704-02-3 (C) 2014 IADIS

[28] Marquès $P$ (2013) Impacto de las TIC en la educación: funciones y limitaciones. 3C TIC 2(1):2-15

[29] Narzoles, D.G., (2013). The Effect of Multi-Media Instruction on Student Learning, Journal of Education and Practice. 4(5) 126-131. ISSN 2222-1735, ISSN 2222-288X

[30] Ocal, T. (2016) The Effect of Field Trips to Historical-Cultural Heritage Sites on Teacher Candidates' Academic Knowledge and Their Sensitivity. Creative Education, 7, 376-386. DOI: 10.4236/ce.2016.72037.

[31] Ilhan, G.O, and Oruç, S. (2016). Effect of the use of multimedia on students' performance: A case study of social studies class. Educational Research and Reviews. Vol. 11(8), pp. 877-882, 23 April, 2016 DOI: 10.5897/ERR2016.2741 Article Number: 5047F0A58349 ISSN 1990-3839

[32] Ocampo, M.C., \& Delgado, P. (2014). Basic education and cultural heritage: prospects and challenges. International journal of humanities and social science, 4, 201-209.

[33] Oğuz, M. Ö. (2013). Intangible cultural heritage as a Term. Milli Folklor, 25 (100), 5-13.

[34] Ott, M. M., \& Pozzi, F. F. (2011). Towards a new era for cultural heritage education: Discussing the role of ICT. Computers in Human Behavior, 27, 1365-1371. doi:10.1016/j. chb.2010.07.031

[35] Pedroso, J.E.P., (2020). Understanding Casa Mariquit as an Ilonggo Cultural Heritage Site: Towards the Development of a Video Documentary Instructional Material, BIMP-EAGA Journal of Sustainable Tourism Development. 9(1), 4051DOI: https://doi.org/10.51200/bimpeagajtsd.v9i1.3247

[36] Pedroso, J.E.P., (2021). Students' Views from Webinars: A Qualitative Study. International Journal of Arts and Humanities Studies (IJAHS), 1(1), 36-44. ISSN: 2754-4311, DOI: 10.32996/ijahs

[37] Santos, L. C. (2021). Relationship between Students' Historical Awareness and their Appreciation of Local Cultural Heritage. International Journal of Multidisciplinary: Applied Business and Education Research, 2(6),520-527. https://ijmaberjournal.org/index.php/ijmaber/article/view/136

[38] Sevier, B. (2005). "What does this have to do with us?" Pursuing transformative possibilities and cultural relevancy in a social foundations teacher education course. Theory \& Research in Social Education, 33, 347-375. doi:10.1080/00933104.2005.10473286

[39] Shah, I. \& Khan, M., (2015). Impact of Multimedia-aided Teaching on Students' Academic Level, US-China Education Review A, 5(5), 349-360 DOI: 10.17265/2161-623X/2015.05.006

Achievement and Attitude at Elementary 
[40] Smith1, R. B. (2007). R.G. Collingwood's definition of historical knowledge. History of European Ideas, 33(3), 350-371. https://doi.org/10.1016/j.histeuroideas.2006.11.010

[41] Srivastava, S. (2015). A study of awareness of cultural heritage among the teachers at the university level. Universal Journal of Educational Research, 3, 336-344. doi:10.13189/ ujer.2015.030505

[42] Stachowski, L. L., \& Visconti, V. (1997). Adaptations for success: U.S. student teachers living and teaching abroad. International Education, 26, $5-20$

[43] Tarek S. A. | (2017) Assessment of students' awareness of the national heritage (Case study: The preparatory year students at the University of Hail, Saudi Arabia), Cogent Social Sciences, 3:1, 1306202, DOI: 10.1080/23311886.2017.1306202

[44] Tören, E., Kozak, N., Demiral, G.N. (2012). The role of public institutions in the protection of cultural Aksaray Üniversitesi IiBF Dergisi, 4(2), 6988.

[45] Vecco, M. (2010). A definition of cultural heritage: From the tangible to the intangible, Journal of Cultural Heritage, 11, $321-324$.

[46] $\mathrm{Wu}, \mathrm{H}$. (2011). Constructing culturally relevant pedagogy in Chinese heritage language classrooms: A multiple-case study. Online submission.

[47] Yazıcı, Ö. (2016). Student Perceptions concerning geographical elements on Turkish banknotes of republic period. The Journal of International Social Research, 9 (46), 366-380.

[48] Yeşilbursa, C. C., \& Barton, K. (2011). Preservice teachers' attitudes toward the inclusion of heritage education in elementary social studies. Journal of Social Studies Education Research, 2(2), 1- 21.

[49] Yılmaz, K. Ş., Şahbudak, E., Akkuş, G. Işkın, M. (2017). Cultural heritage awareness: a study of an application for the Cumhuriyet University Students. Journal of Academic Researches and Studies, 9 (16), 86-100. 